\title{
Genetic Variability and Structure of The Wild Service Tree (Sorbus torminalis (L.) Crantz) in Poland
}

\author{
By L. Bednorz ${ }^{1), *)}$, L. MyczKo ${ }^{2)}$ and P. Kosiński ${ }^{1,3)}$
}

(Received 22 $2^{\text {nd }}$ December 2005)

\begin{abstract}
Sorbus torminalis is a rare forest tree species in Poland. Allelic and genotypic structures at 25 isozyme gene loci were observed in 20 populations from Poland, situated mainly along a latitudinal gradient. Levels of genetic diversity were high both at the species level $\left(P=44 \%, H_{e}=0.435\right)$ and within populations (mean $P=40.8 \%$, mean $\left.H_{e}=0.373\right)$. Levels of differentiation among populations were relatively high $\left(F_{S T}=0.17\right)$ and a noticeable geographic structure of this differentiation was detected. The population in the 'Brekinia' reserve had a unique genetic structure of a clonal population and was the most distinct from the other populations.
\end{abstract}

Key words: electrophoresis, isozymes, genetic diversity, population differentiation, Sorbus torminalis.

\section{Introduction}

The wild service tree, Sorbus torminalis (L.) Crantz (Rosaceae), is a scattered temperate forest tree. It is a diploid $(2 \mathrm{n}=34)$, insect-pollinated species, whose seeds are dispersed by birds and mammals. S. torminalis can also reproduce asexually by suckers. The species is native to Europe, Asia Minor, Caucasus and north-western Africa. In Poland the $S$. torminalis range reaches its north-eastern limits. The species is fully protected by law and considered to be rare and endangered. According to the latest data there are 73 localities of the wild service tree in Poland and its total resources in our forests are estimated at about 2550 trees (BEDNORZ, 2003).

Extensive examinations of genetic diversity in S. torminalis have been carried out in France and less detailed in Central Europe (PRAT and DANIEL, 1993; Demesure et al., 2000; OdDOU-Muratorio et al., 2001; BIEDENKOPF et al., 2006). In Poland some preliminary genetic studies on the species have been initiated recently (KRZAKOWA and BEDNORZ, 1999; BEDNORZ and KRZAKOwA, 2002; BEDNORZ et al., 2004).

The objective of this study was to assess the level and distribution of genetic variation of $S$. torminalis in Poland, as this may be of prime importance for creating a programme of preserving its genetic resources.

1) Department of Botany, August Cieszkowski Agricultural University of Poznań, Poland.

2) Department of Genetics, Adam Mickiewicz University of Poznań, Poland.

${ }^{3}$ ) Institute of Dendrology, Polish Academy of Sciences, Kórnik, Poland.

*) Correspondence: LeSzer Bednorz, Department of Botany, August Cieszkowski Agricultural University, Wojska Polskiego 71c, 60-625 Poznań, Poland. Tel. 4861 848-76-99. E-mail: lbednorz@au.poznan.pl

\section{Materials and Methods \\ Plant materials and isozyme analysis}

Twenty Polish populations of S. torminalis were sampled in March 2004 (Fig. 1, Table 1). Dormant buds were collected from 8 to 41 trees per population (in most cases separated from each other by at least $20 \mathrm{~m}$ to avoid sampling the same clone). A number of sampled trees reflected to some extent the population size, expressed in the number of trees (correlation coefficient $r=0.7174$, $\mathrm{p}<0.05$ ). Buds (2 to 3 per tree) were ground in the tris$\mathrm{HCl}$ buffer $\mathrm{pH} 7.5$ (WendeL and WeEDEN, 1989). The enzymes were separated in $12 \%$ starch gel, prepared in the lithium-borate electrode buffer $\mathrm{pH} 8.2$, tris-citrate gel buffer $\mathrm{pH}$ 8.2, tris-citrate electrode buffer $\mathrm{pH} 7.0$, and histidine-tris gel buffer $\mathrm{pH} 7.0$ (AsHTON and BRADEN, 1961; ConkLE et al.,1982; Wendel and WeEDEN, 1989). The extracts were stored at $-80^{\circ} \mathrm{C}$ until the electrophoretic analysis. As detailed inheritance analyses have not been carried out in $S$. torminalis, genetic control and the mode of inheritance of isozymes was inferred from other deciduous tree species, e.g. Sorbus aucuparia (RASPÉ et al., 1998) and Pyrus communis (CHEVREAU et al., 1997). Additionally, for better interpretation of obtained zymograms, open-pollinated progeny of three trees with known genotypes was analysed. Fourteen enzyme systems with distinct and reproducible patterns were analysed: MDH, E.C. 1.1.1.37 (malate dehydrogenase, one locus: MDH-B), ME, E.C. 1.1.1.40 (malic enzyme, one locus: ME-A), 6PGD, E.C. 1.1.1.44 (6-phosphogluconate dehydrogenase, two loci: 6PGD-A, B), ADH, E.C. 1.1.1.1 (alcohol dehydrogenase, two loci: ADH-A, B), PGM, E.C. 5.4.2.2 (phosphoglucomutase, two loci: PGM-A, B), PGI, E.C. 5.3.1.9 (phosphoglucose isomerase, one locus: PGI-A), FLE, E.C. 3.1.1.1 (fluorescent esterase, two loci: FLE-A, B), GOT, E.C. 2.6.1.1 (glutamate oxaloacetate transaminase, four loci: GOT-A, B, C, D), GDH, E.C. 1.4.1.3 (glutamate dehydrogenase, one locus: GDH-B), DIA, E.C. 1.6.4.3 (diaphorase, four loci: DIA-A, B, C, D), SDH, E.C. 1.1.1.25 (shikimate dehydrogenase, two loci: SDH-A, B), G6PD, E.C. 1.1.1.49 (glucose-6-phosphate dehydrogenase, one locus: G6PD-A), IDH, E.C. 1.1.1.42 (isocitrate dehydrogenase, one locus: IDH-A), ACO, E.C. 4.2.1.3 (aconitase, one locus: ACO-A). The alleles were numbered from the fastest to the slowest. Standard staining procedures with some minor modification were used (RoTHE, 1994).

\section{Data analysis}

The POPGENE 1.31 (YEH et al., 1999) computer program was used to estimate the main parameters of genetic diversity: $P$, the proportion of polymorphic loci at the $99 \%$ level; $N_{a}$, the average number of alleles per 


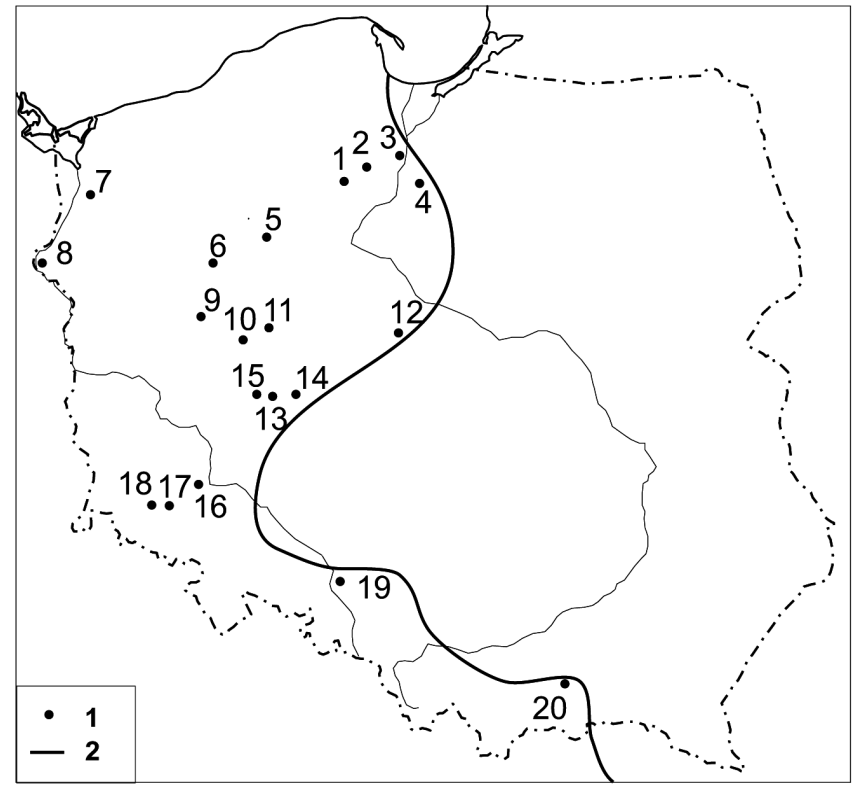

Figure 1. - Geographical distribution of sampled populations of Sorbus torminalis: 1. Localities of sampled populations (as in Table 1), 2. North-eastern range of $S$. torminalis in Poland.

locus; $N_{e}$, the effective number of alleles per locus; $H_{o}$ and $H_{e}$, the observed and expected heterozygosities, which were corrected for small sample size (NEI, 1978). The indices were calculated over polymorphic loci. For each locus in every population, the inbreeding coefficient $\left(F_{I S}\right)$ was computed following WRIGHT (1965), and the Chi-squared test for departure from Hardy-Weinberg equilibrium was performed. To detect genetic differentiation among populations, the test of homogeneity of allele frequencies among populations was performed, and the differentiation coefficient $\left(F_{S T}\right)$, as defined by WRIGHT (1965), was calculated. To evaluate differences in levels of diversity in $H_{e}$ across populations, the coefficient of variation of $H_{e}$ was computed. To find out the relation between population size (number of trees) and levels of genetic diversity within populations the correlation coefficient between $H_{e}$ and population size was calculated. Gene flow, expressed as the average number
Table 1. - Geographical coordinates and numbers of 20 sampled Polish populations of Sorbus torminalis.

\begin{tabular}{|c|c|c|c|c|c|c|}
\hline $\begin{array}{l}\text { No. of } \\
\text { popu- } \\
\text { lation }\end{array}$ & Population & $\begin{array}{c}\text { Latitude } \\
\mathrm{N}\end{array}$ & $\begin{array}{c}\text { Longitude } \\
\mathrm{E}\end{array}$ & $\begin{array}{c}\text { Altitude } \\
(\mathrm{m})\end{array}$ & $\begin{array}{l}\text { Approximate } \\
\text { population } \\
\text { size }\end{array}$ & $\begin{array}{c}\text { Sample } \\
\text { size }\end{array}$ \\
\hline 1 & Tuchola & $53^{\circ} 31^{\prime}$ & $17^{\circ} 53^{\prime}$ & $100-110$ & 200 & 28 \\
\hline 2 & $\begin{array}{l}\text { 'Brzęki im. Z. Czubińskiego' } \\
\text { reserve }\end{array}$ & $53^{\circ} 39^{\prime}$ & $18^{\circ} 22^{\prime}$ & 100 & 100 & 32 \\
\hline 3 & Opalenie & $53^{\circ} 45^{\prime}$ & $18^{\circ} 48^{\prime}$ & $60-70$ & 40 & 25 \\
\hline 4 & Rogóźno & $53^{\circ} 31^{\prime}$ & $18^{\circ} 58^{\prime}$ & $60-95$ & 100 & 32 \\
\hline 5 & Zielonagóra & $53^{\circ} 07^{\prime}$ & $17^{\circ} 16^{\prime}$ & $80-100$ & 100 & 34 \\
\hline 6 & Goraj & $52^{\circ} 53^{\prime}$ & $16^{\circ} 31^{\prime}$ & $50-80$ & 225 & 32 \\
\hline 7 & 'Puszcza Bukowa’' & $53^{\circ} 20^{\prime}$ & $14^{\circ} 38^{\prime}$ & $60-70$ & 20 & 19 \\
\hline 8 & 'Bielinek nad Odrą' reserve & $52^{\circ} 56^{\prime}$ & $14^{\circ} 10^{\prime}$ & $40-60$ & 50 & 34 \\
\hline 9 & Bytyń & $52^{\circ} 28^{\prime}$ & $16^{\circ} 28^{\prime}$ & 100 & 190 & 38 \\
\hline 10 & Wielkopolski National Park & $52^{\circ} 16^{\prime}$ & $16^{\circ} 48^{\prime}$ & $85-100$ & 40 & 21 \\
\hline 11 & Promno & $52^{\circ} 26^{\prime}$ & $17^{\circ} 19^{\prime}$ & $80-100$ & 18 & 8 \\
\hline 12 & $\begin{array}{l}\text { 'Kawęczyńskie Brzęki' } \\
\text { reserve }\end{array}$ & $52^{\circ} 24^{\prime}$ & $18^{\circ} 37^{\prime}$ & $120-130$ & 40 & 20 \\
\hline 13 & Potarzyca & $51^{\circ} 52^{\prime}$ & $17^{\circ} 24^{\prime}$ & 130 & 30 & 15 \\
\hline 14 & Taczanów & $51^{\circ} 49^{\prime}$ & $17^{\circ} 46^{\prime}$ & 130 & 30 & 24 \\
\hline 15 & Piaski & $51^{\circ} 49^{\prime}$ & $17^{\circ} 12^{\prime}$ & 130 & 160 & 29 \\
\hline 16 & 'Brekinia' reserve & $51^{\circ} 17^{\prime}$ & $16^{\circ} 21^{\prime}$ & 110 & 40 & 24 \\
\hline 17 & Jawor & $51^{\circ} 01^{\prime}$ & $16^{\circ} 08^{\prime}$ & $300-395$ & 480 & 41 \\
\hline 18 & Lubiechowa & $51^{\circ} 00^{\prime}$ & $15^{\circ} 50^{\prime}$ & 360 & 25 & 10 \\
\hline 19 & 'Kamień Śląski' reserve & $50^{\circ} 33^{\prime}$ & $18^{\circ} 05^{\prime}$ & $180-190$ & 70 & 26 \\
\hline 20 & Białowodzka Góra & $49^{\circ} 41^{\prime}$ & $20^{\circ} 38^{\prime}$ & $500-550$ & 300 & 39 \\
\hline
\end{tabular}

of immigrants per generation $(\mathrm{Nm})$, was estimated from overall allelic differentiation among populations, as measured by the $F_{S T}$ coefficient, using the formula: $N m=0.25\left(1-F_{S T}\right) / F_{S T}$.

The similarity between pairs of populations was measured by NEI's (1978) unbiased genetic distances corrected for small sample sizes. The dendrogram was produced basing on this distance, using the UPGMA method (HARTL and ClarK, 1989). A Mantel test, using 1000 random permutations, was performed with the IBD software (BOHONAK, 2002), to test for significance of the correlation between genetic (NEI's) and geographical distances among populations.

\section{Results}

Allozyme diversity at species and population levels

From 25 investigated putative gene loci, 11 loci (MDHB, ME-A, 6PGD-B, ADH-B, PGM-A, PGM-B, PGI-A, FLE-B, GOT-C, GDH-B, DIA-C) proved to be polymorphic, whereas 14 loci (6PGD-A, ADH-A, FLE-A, GOT-A, GOT-B, GOT-D, DIA-A, DIA-B, DIA-D, SDH-A, SDH-B, G6PD-A, IDH-A, ACO-A) were monomorphic. The num-

Table 2. - Genetic diversity and gene flow estimates per locus among the Polish populations of Sorbus torminalis.

\begin{tabular}{|l|c|c|c|c|c|c|c|}
\hline Locus & $N_{a}$ & $N_{e}$ & $H_{o}$ & $H_{e}$ & $F_{I S}$ & $F_{S T}$ & $N m$ \\
\hline MDH & 2 & 1.919 & 0.602 & 0.479 & -0.402 & 0.075 & 3.089 \\
ME & 4 & 2.913 & 0.621 & 0.657 & -0.079 & 0.154 & 1.371 \\
6PGD & 2 & 1.456 & 0.313 & 0.313 & -0.216 & 0.179 & 1.144 \\
ADH & 3 & 2.211 & 0.454 & 0.548 & 0.007 & 0.125 & 1.749 \\
PGM-A & 2 & 1.506 & 0.277 & 0.336 & -0.149 & 0.263 & 0.700 \\
PGM-B & 2 & 1.999 & 0.336 & 0.500 & 0.101 & 0.263 & 0.700 \\
PGI & 4 & 2.077 & 0.573 & 0.519 & -0.316 & 0.139 & 1.544 \\
FLE & 2 & 1.411 & 0.241 & 0.292 & -0.017 & 0.184 & 1.108 \\
Got-C & 2 & 1.930 & 0.453 & 0.482 & -0.156 & 0.209 & 0.945 \\
GDH & 3 & 1.634 & 0.465 & 0.388 & -0.280 & 0.077 & 3.003 \\
DIA & 2 & 1.375 & 0.262 & 0.273 & -0.229 & 0.226 & 0.855 \\
\hline Mean & 2.546 & 1.857 & 0.418 & 0.435 & -0.157 & 0.167 & 1.245 \\
SD & 0.820 & 0.456 & 0.140 & 0.123 & & & \\
\hline
\end{tabular}

$N_{a}$ - number of alleles per locus, $N_{e}$ - effective number of alleles, $H_{o}$ - observed heterozygosity, $H_{e}$ - expected heterozygosity, $F_{I S}$ - heterozygote deficit, $F_{S T}$ - differentiation coeficient, $\mathrm{Nm}$ - gene flow, $S D$ - standard deviation. 
ber of alleles detected at each polymorphic locus ranged from 2 to 4, with a mean of 2.55 (Table 2). The highest number of alleles (4) was noted for ME and PGI. The ME-A locus was also characterized by the highest effective number of alleles, 2.913. The average values of observed and expected heterozygosities were 0.4178 and 0.4354 , respectively. At the species level the percentage of polymorphic loci (P) was $44 \%$.

Levels of genetic variation within each population are surveyed in Table 3 . The ranges of percentage of polymorphic loci $(P)$, mean number of alleles per locus $\left(N_{a}\right)$ and expected heterozygosity $\left(H_{e}\right)$ were $24-44 \%$, 1.546-2.455 and 0.193-0.473, respectively. The mean values of $P, N_{a}$ and $H_{e}$ over all populations were $40.8 \%$, 2.146 and 0.373 , respectively. Populations 2, 19, 10 and 5 were characterised by the highest levels of genetic variation within populations. Populations 16, 8 and 4 were characterised by the lowest levels of genetic variation (population 16 was outstanding in this respect). There was no significant correlation between population size and levels of genetic diversity within populations $\left(r=-0.1349\right.$ for $\left.H_{e}\right)$. The coefficient of variation of $H_{e}$ across all 20 populations was 0.18 .

The $F_{I S}$ values varied considerably among loci, from -0.402 (MDH) to 0.101 (PGM-B) and were negative at 9 loci, and positive at only 2 loci ( 8 out of 11 loci exhibited significant departure of genotypic frequencies, compared to the Hardy-Weinberg expectations). The combined value over all loci was -0.157 , indicating a small but noticeable excess of heterozygotes (Table 2). At the population level, the ratio of positive to negative inbreeding coefficients $\left(F_{I S}\right)$ was 3:17 (Table 3). Out of 204 tests for departure from Hardy-Weinberg expectations, 30 were significant: 18 for heterozygote excess and 12 for heterozygote deficiency $(p<0.01)$. This indicates a tendency towards heterozygote excess within most of the studied populations of $S$. torminalis.

\section{Spatial structure of variation and gene flow}

The coefficient of differentiation among populations $\left(F_{S T}\right)$ ranged from 0.075 to 0.263 across loci, with an overall value of 0.167 (Table 2). Most alleles were found in all the studied populations. However, allele GDH 3 was present only in 2 populations (Tuchola in NW Poland and Lubiechowa in S Poland) and allele PGI 4 was only observed in 4 populations ( 2 from NW Poland: 'Brzęki im. Czubińskiego' reserve, Opalenie; and 2 from S Poland: 'Kamień Śląski' reserve, Białowodzka Góra). Also allele ME 4 was relatively rare, present in 8 populations. Gene flow among 20 studied populations was relatively low $(\mathrm{Nm}=1.25)$.

A Mantel test showed a positive, statistically significant correlation $(\mathrm{r}=0.410, \mathrm{p}=0.000)$ between genetic and geographical distances. In the UPGMA dendrogram based on NEI's (1978) unbiased distance, populations tended to cluster according to geographic regions. All populations from north-western Poland (Pomerania) together with 4 populations from the mid-western region (Wielkopolska) formed 1 bigger group. The remaining populations from Wielkopolska clustered with 3 populations from southern Poland (Fig. 2). Only 2 populations from south-western Poland (Lubiechowa
Table 3. - Parameters of genetic variability and inbreeding coefficients of Polish populations of Sorbus torminalis.

\begin{tabular}{|c|c|c|c|c|c|c|}
\hline $\begin{array}{c}\text { Popu- } \\
\text { lation }\end{array}$ & $P$ & $N_{a}$ & $N_{e}$ & $H_{o}$ & $H_{e}$ & $F_{I S}$ \\
\hline 1 & 44 & 2.182 & 1.597 & 0.432 & 0.348 & -0.198 \\
2 & 44 & 2.455 & 1.882 & 0.441 & 0.442 & -0.029 \\
3 & 40 & 2.273 & 1.772 & 0.527 & 0.404 & -0.229 \\
4 & 36 & 2.182 & 1.519 & 0.270 & 0.286 & 0.086 \\
5 & 40 & 2.273 & 1.908 & 0.425 & 0.445 & 0.000 \\
6 & 40 & 2.182 & 1.657 & 0.402 & 0.367 & -0.085 \\
7 & 40 & 2.182 & 1.690 & 0.452 & 0.363 & -0.223 \\
8 & 36 & 1.182 & 1.535 & 0.349 & 0.295 & -0.134 \\
9 & 44 & 2.273 & 1.759 & 0.421 & 0.404 & -0.072 \\
10 & 44 & 2.182 & 1.895 & 0.530 & 0.473 & -0.165 \\
11 & 36 & 1.909 & 1.678 & 0.375 & 0.374 & 0.021 \\
12 & 44 & 2.273 & 1.819 & 0.477 & 0.426 & -0.118 \\
13 & 44 & 2.273 & 1.812 & 0.473 & 0.404 & -0.101 \\
14 & 44 & 2.273 & 1.754 & 0.399 & 0.388 & 0.016 \\
15 & 44 & 2.364 & 1.843 & 0.486 & 0.414 & -0.158 \\
16 & 24 & 1.546 & 1.371 & 0.367 & 0.193 & -0.360 \\
17 & 44 & 2.273 & 1.552 & 0.381 & 0.336 & -0.112 \\
18 & 40 & 2.091 & 1.599 & 0.391 & 0.346 & -0.159 \\
19 & 44 & 2.364 & 1.848 & 0.454 & 0.430 & -0.091 \\
20 & 44 & 2.182 & 1.592 & 0.395 & 0.329 & -0.158 \\
\hline Mean & 40.8 & 2.146 & 1.704 & 0.422 & 0.373 & -0.113 \\
SD & 4.959 & 0.296 & 0.149 & 0.062 & 0.066 & 0.103 \\
\hline
\end{tabular}

$P$ - percentage of polymorphic loci, $N_{a}$ - number of alleles per locus, $N_{e}$ - effective number of alleles, $H_{o}$ - observed heterozygosity, $H_{e}$ - expected heterozygosity, $F_{I S}$ - heterozygote deficit.

and the 'Brekinia' reserve) showed noticeable divergent characters. The population from Lubiechowa is distinguished from the others by the highest frequencies of 2 rare alleles (GDH 3 and ME 4) and absence of 3 common alleles (ME 2, ME 3 and Got-C 2). It is a small population consisting of relatively young individuals. The population from the 'Brekinia' reserve is the least differentiated among the investigated populations (only 6 poly-

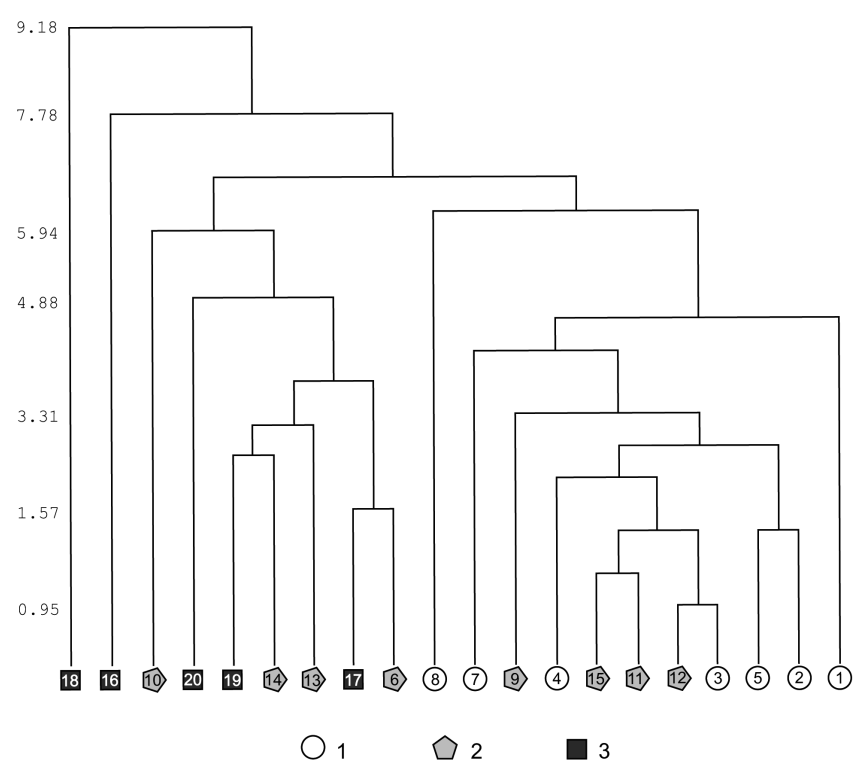

Figure 2. - UPGMA clustering of 20 populations of Sorbus torminalis based on Nei's genetic distance: 1. Pomerania, 2. Wielkopolska, 3. Southern Poland. 
morphic loci) and has a genetic structure of a clonal population. Our study revealed that among 24 examined trees, 23 had an identical genotype and only 1 tree had a different genotype. This single tree had also 2 alleles unique to the population. Currently the population consists of about 40 trees and numerous sprouts growing on an area of 1 ha.

\section{Discussion}

The levels of genetic variation of $S$. torminalis in Poland, both within and between populations, are high. In comparison to the mean values given by HAMRICK and NASON (1996) for species with the same breeding system, i.e. outcrossed, animal-pollinated $\left(P=35.9 \%, H_{e}=\right.$ 0.124 within populations; $P=50.1 \%, H_{e}=0.167$ within species), our estimates of genetic variation (using all loci) in $S$. torminalis were similar $\left(P=40.8 \%, H_{e}=0.164\right.$ within populations and $P=44 \%, H_{e}=0.191$ within species). According to HAMRICK and others (1992), woody species maintain more variation within species and within populations than species with other life forms, as mean estimates of genetic variation for the long-lived woody species are higher $\left(P=49.3 \%, H_{e}=0.148\right.$ within populations; $P=65.0 \%, H_{e}=0.177$ within species). Similar values were obtained for $S$. torminalis by DEMESURE and others (2000) in France and Central Europe $\left(P=57 \%, H_{e}=0.156\right.$ within populations; $P=66.0 \%, H_{e}=0.185$ within species). Although the percent of polymorphic loci was higher than in our study, the expected heterozygosity - which is the most useful and widespread measure of genetic variation (HEDRICK, 2000) - was slightly lower than that observed in Polish populations. Our populations of wild service trees are located on the north-eastern limits of the species range. Hence, a comparable level of polymorphism detected in $S$. torminalis in Poland and in the distribution centre of the species in France and Central Europe might be surprising. RASMUSSEN and KOLLMANN (2004) showed that generative reproduction of $S$. torminalis is reduced on its northern distribution limit in Denmark and that it might be negatively affected by pollen limitation and inbreeding effects. Such a situation results in decreasing genetic diversity and population viability. However, in Polish populations on north-eastern distribution limits, the sexual reproduction of $S$. torminalis is abundant and some gene flow among populations is observed. Hence, levels of genetic diversity in the wild service tree in Poland and its distribution centre are comparable. Our results for $S$. torminalis also indicate that the genetic diversity is equally distributed in Poland. The coefficient of variation of $H_{e}(0.18)$ is similar to that observed in $S$. torminalis in France (0.20) and in a compilation of 62 outcrossing tree species (0.17) (DEMESURE et al., 2000).

The size of 20 populations of $S$. torminalis examined in Poland varied considerably, from 18 individuals to nearly a five hundred individuals. Usually, smaller local populations within a species contain less variation than larger populations due to genetic drift and inbreeding effects (ELlSTRAND and ELAM, 1993). However, some studies show that the levels of genetic diversity within populations are not positively correlated with population size (e.g. LESSICA and ALLENDORF, 1992; ElLSTRAND and Elam, 1993; Oostermeiser et al., 1994; GodT et al., 1995). Such a situation happened in the case of our study. We did not find any significant relation between population size and levels of genetic diversity. Populations 7, 11 and 18, which are the smallest among the 20 studied populations, maintained relatively high levels of genetic diversity.

A small but noticeable heterozygote excess within most of the examined Polish populations of $S$. torminalis was revealed in our study. This may be explained in a few ways. First of all, the wild service tree is an outcrossing species to a large extent. Only a very low rate of self-pollination has been found in $S$. torminalis (Demesure-Mush and Oddou-Muratorio, 2004; RASMUSSEN and KoLLMANN, 2004). It is also currently known that at least a weakened self-incompatibility system exists in the species (WoJCIECHOWSKI and BEDNORZ, 2000; Demesure-Mush and Oddou-Muratorio, 2004; RASMUSSEN and KollmanN, 2004). Self-incompatibility itself limits the crosses between closely related, genetically similar individuals, and thus may increase the level of heterozygosity in local populations. The high level of heterozygosity was observed not only in large populations with effective sexual reproduction but also in populations of smaller size. According to HEDRICK (2000), a small number of parents may cause an excess of heterozygosity in the progeny because of chance differences in allelic frequencies in the female and male parents. It must be also remembered that any population can undergo occasional fluctuations, and that some of currently small populations may be the remains of much larger populations existing in the past, when S. torminalis was more abundant in our forests. ELLSTRAND and ELAM (1993) have pointed out that with marked drops in population size, heterozygosity often remains relatively unchanged as long as population size rebounds rapidly. It is possible that such situations sometimes happened in the case of the wild service tree. The high level of heterozygosity in $S$. torminalis recorded in Polish populations is an advantageous feature. Some studies have previously suggested that highly heterozygous organisms are better able to cope with fluctuating environments (HUENNEKE, 1991; ElLSTRAND and ElAM, 1993).

The majority of forest tree species are characterised by a low level of variation among populations. According to HAMRICK and others (1992), the mean $F_{S T}$ for trees with animal-dispersed seeds is equal to 0.05 . The value of this parameter observed in $S$. torminalis in Poland (0.17) is much higher. It is also slightly higher than previously reported $(0.10$ and 0.15$)$ for the species in France (Prat and DAniel, 1993; Demesure et al., 2000). DEMESURE and others (2000) noticed that relatively high $F_{S T}$ values were also reported for other scattered species having small populations, and that population subdivision promotes differentiation. In Poland S. torminalis has a scattered distribution, consisting mainly of nonrandomly mating small populations. The level of gene flow observed among studied populations of the wild service tree was relatively low. Therefore genetic drift can 
be here an important factor in differentiation of populations. In spite of relatively high genetic diversity of $S$. torminalis in Poland, genetic resources of the species may be endangered, because of spatial isolation of most populations and low levels of gene flow between them. Hence, some conservation measures should be undertaken to counteract low levels of gene flow between populations (increase the dynamics of gene flow between populations). Further studies based on direct estimates of gene flow would be also desirable.

The high level of differentiation among populations can also be explained by founder effects. It has already been ascertained that $S$. torminalis has a metapopulation-like dynamics, with frequent extinction and recolonization events and efficient seed dispersal strategies (Demesure et al., 2000; OdDOu-Muratorio et al., 2001; DEMESURE-Mush et al., 2004). In such species the seed movements into an empty patch of favourable habitat are the basic mechanism for the foundation of new local subpopulations (MCCAULEY, 1994). This fact explains the low pollen/seed migration ratio in such systems (McCauley, 1997). OdDOU-Muratorio and others (2001) proved that neither pollen- nor seed-mediated gene flow was predominant in $S$. torminalis. The value of pollen/seed migration ratio obtained in $S$. torminalis $(r=2.21)$ was one of the lowest observed in woody species. This indicates the importance of seed dispersal. The efficiency of the seed-mediated gene flow may be explained by the mode of fleshy fruit dispersion by mammals and birds (SNOw and SNOw, 1988; GRIME et al., 1988) both over short and longer distances (ODDOUMURATORIO et al., 2001). The extinction-recolonization dynamics of the wild service tree should imply special silviculture management (e.g. leaving free enlightened patches in the woods, natural regeneration promotion, competition control).

A positive, statistically significant correlation between genetic and geographical distances among Polish populations was found in our study. Also some divergence of populations from northern and southern Poland was ascertained. The post-glacial history might be important in the current pattern of differentiation. There are two most possible directions of $S$. torminalis migration to Poland: (1) from the south, through the Morawska Gate and along the Dunajec and Poprad valleys; and (2) from the west, along the Torun-Eberswald proglacial stream valley. However, the origin of particular wild service tree populations remains unknown. The studies at the European scale indicated the presence of various refuges in Europe during the last glaciations, but no phylogeographic structure was found at a regional scale (PETIT et al., 2003). The same authors pointed out that intensive seed movement and numerous extinction/recolonization events since the last glaciation could have blurred a preexisting phylogeographic structure.

The current genetic structure of 20 Polish populations of the wild service tree was ascertained in our study. As pointed out by HEDRICK (2000), in small populations, the allelic frequency can undergo large fluctuations in different generations in an unpredictable pattern and can result in chance fixation or loss of an allele. Therefore, the currently observed genetic structure may be short- lived, at least in the smallest populations of $S$. torminalis examined in Poland. Although numerous examples of vegetative propagation by root suckers in S. torminalis are known, the intensity of this phenomenon and its impact on the genetic structure of the population observed in the 'Brekinia' reserve was outstanding. The population will be the subject of further studies.

The result of our investigation should be applied to conservation management of the genetic resources of wild service tree on its distribution limits in Poland. The general strategy including both in situ and ex situ measures has been recently developed by members of the EUFORGEN Noble Hardwoods Network (DEMESUREMush and Oddou-Muratorio, 2004).

\section{Acknowledgements}

These studies were supported by the State Committee for Scientific Research (KBN), grant no 2 P06L 01326.

\section{References}

Ashton, G. C. and A. W. H. Braden (1961): Serum $\beta$-globulin polymorphism in mice. Austrial. J. Biol. Sci., 14, 248-254.

Bednorz, L. (2003): The wild service tree (Sorbus torminalis (L.) Crantz) in Polish forests, pp. 335-340 in Ksztaltowanie i ochrona środowiska leśnego, edited by A. T. MileR, Wydawnictwo Akademii Rolniczej im. Augusta Cieszkowskiego, Poznań.

Bednorz, L. and M. KRzAKowa (2002): Phosphoglucose isomerase (PGI) polymorphism in Sorbus torminalis (L.) Crantz. Acta Soc. Bot. Pol. 71, 2, 121-124.

BeDnorz, L., L. MYczKo and P. KosińsKi (2004): Isozyme polymorphism and genetic structure of the population of Sorbus torminalis (L.) Crantz from the Bytyn Forest (Poland). J. Appl. Genet. 45, 3: 321-324.

Biedenkopf, S., C. Ammer and G. MÜller-Stark (2006): Genetic aspects of seed harvests for the artificial regeneration of Wild service tree (Sorbus torminalis [L.] Crantz). New Forests (in press).

BoHonAK, A. J. (2002): IBD (Isolation By Distance): a program for analyses of isolation by distance. J. Hered. 93, 153-154.

Chevreau, E., S. Leuliette and M. Gallet (1997): Inheritance and linkage of isozyme loci in pear (Pyrus communis L.). Theor. Appl. Genet. 94, 498-506.

Conkle, M. T., P. D. Hodgskiss, L. B. Nunnally and S. C. HUNTER (1982): Starch gel electrophoresis of conifer seeds: a laboratory manual. Pacific Southwest Forest and Range Experimental Station, USDA Forest Service, Berkeley, CA., General Tech. Report, PSW-64.

Demesure, B., B. Leguerroué, G. Lucchi, D. Prat and R. J. PETIT (2000): Genetic variability of a scattered temperate forest tree: Sorbus torminalis L. (Crantz). Ann. For. Sci. 57, 63-71.

Demesure-Mush, B. and S. Oddou-Muratorio (2004): EUFORGEN Technical Guidelines for genetic conservation and use for wild service tree (Sorbus torminalis). International Plant Genetic Resources Institute, Rome, Italy.

Ellstrand, N. C. and D. R. Elam (1993): Population genetic consequences of small population size: Implications for Plant Conservation. Annu. Rev. Ecol. Syst. 24, 217-242. 
Godt, M. W. J., J. L. HAMrick and S. Braton (1995): Genetic diversity in a threatened wetland species, $\mathrm{Hel}$ lonias bullata (Liliaceae). Conserv. Biol. 9, 596-604.

Grime, J. P., J. G. Hodgson and D. R. HunT (1988): Comparative plant ecology: a functional approach to common British species. Unwin Hyman, London.

Hamrick, J. L., M. J. W. Godt and S. L. Sherman-Broyles (1992): Factors influencing levels of genetic diversity in woody plant species. New For. 6, 95-124.

HAMRICK, J. L. and J. D. NASON (1996): Consequences of dispersal in plants, pp. 203-236 in Population dynamics in ecological space and time, edited by O. E. RoDHES, R. K. Chesser and M. H. Smith, University of Chicago Press, Chicago.

HartL, D. L. and A. G. Clark (1989): Principles of population genetics. $2^{\text {nd }}$ ed. Sinauer Associates, Sunderland, Massachusetts.

HEDRICK, P. W. (2000): Genetics of populations. $2^{\text {nd }}$ ed. Jones and Bartlet Puublishers, Sudbury, Massachusetts.

HUENNEKE, L. F. (1991): Ecological implications of variation in plant populations, pp. 31-44 in Genetics and Conservation of Rare Plants, edited by D. A. FALK and K. E. Holsinger, Oxford University Press, New York.

LESsiCA, P. and F. W. AllendoRF (1992): Are small populations of plants worth preserving? Conserv. Biol. 6, $135-139$.

McCauley, D. E. (1994): Contrasting the distribution of chloroplast DNA and allozyme polymorphism among local populations of Silene alba: implications for studies of gene flow in plants. Proc. Natl. Acad. Sci. USA. 17, 8127-8131.

MCCAUleY, D. E. (1997): The relative contributions of seed and pollen movements to the local genetic structure of Silene alba. J. Hered. 88, 257-263.

KRZAKOWA, M. and L. BEDNORZ (1999): Electrophoretic evidence of monomorphism in the Wild Service Tree, Sorbus torminalis (L.) Crantz population from 'Bytyńskie Brzęki’ preserve (western Poland). Rocz. Dendrol. 47, 45-51.

NEI, M. (1978): Estimation of average heterozygosity and genetic distance from a small number of individuals. Genetics 89: 583-590.
Oddou-Muratorio, S., B. Le Guerroue, D. Guesnet and B. Demesure (2001): Pollen-versus seed mediated gene flow in a scattered forest tree species. Evolution 55, 6, 1123-1135.

OostermeiJer, J. G. B., M. W. van EiJCK and J. C. M. DEN NIJS (1994): Offspring fitness in relation to population size and genetic variation in the rare perennial plant species Gentiana pneumonanthe (Gentianaceae). Oecologia 97, 289-296.

Petit, R. J., I. Aguinagalde, J. L. De Beaulieu, C. BitTKAU, S. Brewer, R. Chaddadi, R. EnNos, S. Fineschi, D. Grivet, M. Lascoux, A. Mohanty, G. Müller-Stark, B. Demesure-Mush, A. Palmé, J. P. Martin, S. Rendell and G. G. VendRAMIN (2003): Glacial refugia: Hotspots but not melting pots of genetic diversity. Science $\mathbf{3 0 0 0}$, 1563-1565.

PRAT, D. and C. DANIEL (1993): Variabilité génétique l'Alisier torminal et du genere Sorbus. Rev. For. Fr. 45, 3, 216-228.

Rasmussen, K. K. and J. Kollmann (2004): Poor sexual reproduction on the distribution limit of the rare tree Sorbus torminalis. Acta Oecologica 25, 211-218.

RAspé, O., A.-L. Jacquemart and J. DE Sloover (1998): Isozymes in Sorbus aucuparia (Rosaceae: Maloideae): genetic analysis and evolutionary significance of zymograms. Int. J. Plant Sci. 159, 627-636.

Rothe, G. M. (1994): Electrophoresis of Enzymes. Springer-Verlag, Berlin Heidelberg New York.

Snow, B. and D. SNow (1988): Birds and berries: a study of an ecological interaction. T\&AD Poyser, London.

WENDEL, J. F. and N. F. WEEDEN (1989): Visualization and interpretation of Plant Isozymes, pp. 5-45 in Isozymes in plant biology, edited by D. E. Soltis and P. S. Soltis, Dioscorides Press, Oregon.

Wojciechowski, A. and L. BeDNORZ (2000): Estimation of mating-compatibility of the wild service tree (Sorbus torminalis (L.) Crantz) by observing pollen tube germination. J. Appl. Genet. 41, 4, 253-258.

WRIGHT, S. (1965): The interpretation of population structure by $F$-statistics with special regard to systems of mating. Evolution 19, 395-420.

YeH, F. C., R.-C. YANG and T. Boyle (1999): POPGENE Version 1.31 Microsoft Windows-based Freeware for Population Genetic Analysis. University of Alberta.

\title{
Parental and Consensus Linkage Maps of Eucalyptus globulus Using AFLP and Microsatellite Markers
}

\author{
By J. S. Freeman ${ }^{1)}{ }^{*}$ ), B. M. Potts ${ }^{1)}$, M. ShePherD ${ }^{2)}$ and R. E. Vaillancourt ${ }^{1)}$
}

(Received $5^{\text {th }}$ January 2006)

\footnotetext{
1) Cooperative Research Centre for Sustainable Production Forestry and School of Plant Science, University of Tasmania, Private Bag 55, Hobart, Tasmania 7001, Australia.

2) Cooperative Research Centre for Sustainable Production Forestry, Centre for Plant Conservation Genetics, Southern Cross University, NSW 2480, Australia.

*) Corresponding author: email: jsfreema@utas.edu.au
}

\begin{abstract}
Parental and consensus maps were constructed in an $\mathrm{F}_{2}$ inter-provenance cross of Eucalyptus globulus, using amplified fragment length polymorphism (AFLP) and microsatellite (or simple sequence repeats [SSR]) markers. The female map had 12 linkage groups and 118 markers, comprising 33 SSR and 85 AFLP loci. The
\end{abstract}

